\title{
Comparative Study of Antioxidant Activity between Basic and Convenience Foods
}

\author{
Irina Ioannou (Corresponding author) \\ ENSAIA-INPL-LIBio, 2 avenue de la forêt de Haye \\ B. P. 172, Vandoeuvre Les Nancy 54505, France \\ Tel: 33-383-595-814 E-mail: irina.ioannou@ensaia.inpl-nancy.fr \\ Aude Hyardin, Céline Charbonnel \& Mohamed Ghoul \\ INPL-ENSAIA - Laboratoire d'Ingénierie des Biomolécules \\ 2 avenue de la Forêt de Haye, B. P. 172, Vandoeuvre lès Nancy Cedex 54505, France
}

$\begin{array}{ll}\text { Received: November 17, } 2011 & \text { Accepted: December 5, } 2011 \quad \text { Published: February 1, } 2012 \\ \text { doi:10.5539/jfr.vln1p143 } & \text { URL: http://dx.doi.org/10.5539/jfr.v1n1p143 }\end{array}$

\begin{abstract}
The behaviour of the antioxidant capacity (TEAC) and the total phenol content (TPC) of basic foods and convenience foods were analysed along the different steps of food preparation. The major loss of TEAC happens during the processing of convenience foods. A database has been constituted on the TEAC and the TPC of basic and convenience foods, commonly consumed by the French population. It showed that the addition of ingredients with high antioxidant activity to a complex preparation contributes to an increase in the total antioxidant capacity, but not in a proportional way. Differences between expected and measured values are $31 \%$ for two ingredients and $14 \%$ for three ingredients. For the TPC, the increase corresponds to the sum of the TPC of the ingredients. It also showed that microwave reheating and food storage, in most cases, did not lead to variations on TEAC and TPC of convenience foods.
\end{abstract}

Keywords: Additive effect, Database, Food functionality, Formulation, Reheating, Storage, Total Phenolic Content (TPC), Trolox Equivalent Antioxidant Capacity (TEAC)

\section{Introduction}

Over the last decade, there has been a great increase in consumer interest in the active role of foods beyond basic nutrition. Foods may provide health benefits identified as food functionalities (Diplock et al., 1999). Among emergent functionalities, antioxidant activity is the most used. Natural phenols, present in plant food could exert their beneficial health effects mainly through their antioxidant activity (Proteggente et al., 2002; Zhou and Yu, 2006) and it is well known that antioxidants may have the capacity to prevent health problems such as cancer, heart and neurological diseases. Indeed, antioxidants can prevent or delay the oxidation process triggered by free radicals and reactive oxygen species in biological systems.

Several basic foods such as fruits and vegetables are rich in anti oxidant molecules and are good for consumer health. However, consumers often have a food diet of cooked or heated products composed of a mixture of several ingredients. Data, available in the literature, on the antioxidant capacity and phenol content of foods, concern mainly basic foods without taking into account either the formulation or the process effects (Menezes et al., 2002). So it would be relevant to evaluate and to follow the evolution of the total phenol content (TPC) and the antioxidant capacity (TEAC) during life steps of convenience foods from its formulation to its consumption.

The measurement of antioxidant capacity has received much attention, but values obtained are often different due to a lack of standardisation of the antioxidant activity assays and to a variation of the composition of the raw materials used. So, to compare TEAC values, the development of a database on the antioxidant activity of some basic foods and also of some convenience foods is needed. This database would be an effective tool for estimating antioxidant consumption (Pellegrini et al., 2003). Thus, the first purpose of the present study was to provide data on the antioxidant capacity of basic and convenience foods commonly consumed by the French population.

The available data are mostly representative of foodstuffs consumed in their raw state. They cannot take into consideration the fact their activity may be changed by both environmental variables (Stahl et al., 2009, Volden et 
al., 2008) and processing (Igual et al., 2010; Murakami et al., 2004). This aspect is of great importance considering that only small amounts of food are consumed in their raw state, whilst most of them need to be processed for safety, quality and economic reasons. Therefore, the second part of this study was designed to evaluate the effect of i) formulation, ii) culinary reheating, and iii) storage on the antioxidant capacity and the total phenol content of convenience foods.

To establish the effect of the formulation, the antioxidant capacity and the phenol content of basic foods and their mixture were evaluated. In fact during the step of formulation, many interactions can occur. However, these interactions have been very little studied. They can be either a negative synergism by means of a possible depletion of the antioxidant activity upon addition of certain species (Pinelo et al., 2004, Wang et al., 2000) or an additive effect (Philpott et al., 2004). The amplitude of these effects is variable depending on the physico-chemical environment ( $\mathrm{pH}$, ionic forces...) and matrix composition.

The effects of culinary reheating and storage steps were then studied. The evolution of antioxidant capacity and phenol content were realized for five convenience foods. The effect of these two operations is still a matter of debate. For some authors, culinary reheating or storage has little impact on antioxidant properties depending on the process and on the foods (Olsson et al., 2010; Price et al., 1997; Tudela et al., 2002). For others, these steps can have a drastic effect (Viña et al., 2007). The verification of these effects was carried out for microwave reheating and refrigeration.

\section{Materials and Methods}

\subsection{Chemical reagents}

The 6-hydroxy-2,5,7,8-tetramethylchroman-2-carboxylic acid (Trolox), 2,2'-azimobis (3-ethylbenzothiazoline-6-sulfonic acid) diammonium salt (ABTS), Folin-Ciocalteu's phenol reagent, sodium carbonate and gallic acid monohydrate (GA) (purity $\geq 98.0 \%$ ), ethanol (purity $\geq 95.0 \%$ ) and all other solvents and chemical were purchased from Sigma- Aldrich chemicals (France). High-purity water was produced in the laboratory using an Alpha-Q system (Millipore, MA).

\subsection{Basic foods and convenience foods}

\subsubsection{Basic foods}

Basic foods are defined as ingredients which can be eaten alone or cooked with other ingredients. The basic foods chosen here are the ingredients of the convenience foods analysed later. We found: vegetables $(n=4$; fresh tomato, yellow onion, green pepper, green olive) and other different foods ( $\mathrm{n}=5$; prepared lentils (D'Aucy), fresh parsley, olive oil, red wine and mustard). Foods were purchased from a local market. Prior to analysis, the samples were prepared as for conventional consumption: fresh vegetables were cleaned, trimmed of inedible portions; lentils were cooked in boiling water.

\subsubsection{Convenience foods}

Convenience foods are defined as a mix of basic foods requiring some processing, designed for ease of consumption. The samples used are sold in France under the brand Marie S.A. The convenience foods chosen are those most sold by the company. Dishes were supplied directly by the factories ( 5 days after manufacturing, in cooled containers). The details of the recipes can be seen in Annex Materials.

- Fresh dishes: prepared dishes $(\mathrm{n}=12)$ are based on fish or meat with accompaniments (rice, potatoes, pasta or others) or based on vegetables. They are sold in individual portions, averaging $300 \mathrm{~g}$. They are already cooked and only need reheating in the microwave-oven.

- Fresh dishes: pies $(n=6)$ are all made of flaky pastry and a binder based on egg and cream. They essentially contain fish or vegetables. They are already cooked and require reheating.

- Deep-frozen dishes $(n=8)$ are based on pasta, rice or potatoes with various seasonings. They are sold in family-size bags, of $1 \mathrm{~kg}$ on average. They are pre-cooked or cooked and only require reheating. Family bags were defrosted at ambient temperature.

\subsection{Methods}

\subsubsection{Sample preparation}

The foods were prepared according to a single procedure. $200 \pm 0.1 \mathrm{~g}$ of all the food samples were homogenized in a high speed blender ( $150 \mathrm{rpm}$ ) for 5 minutes, $20 \pm 0.1 \mathrm{~g}$ of this preparation was mixed with $50 \mathrm{ml}$ ethanol and kept under agitation $(250 \mathrm{rpm})$ at $25^{\circ} \mathrm{C}$ for $30 \mathrm{~min}$ for the extraction of antioxidant compounds (Moure et al., 2001). Then, the mix was centrifuged at $6000 \mathrm{~g}$ for $15 \mathrm{~min}$, the supernatant was collected, and was filtered at $22 \mu \mathrm{m}$. 
Antioxidant activity was determined as soon as possible (within 30 minutes of preparation). $10 \mathrm{ml}$ of the filtrate was evaporated $\left(37^{\circ} \mathrm{C}, 14 \mathrm{mbar}\right)$ and the residue was solubilised in $50 \%$ mono-propylene glycol and $50 \%$ distilled water $(\mathrm{v} / \mathrm{v})$. The aliquot was stored for $24 \mathrm{~h}$ at $-18^{\circ} \mathrm{C}$ and then used for phenol determination.

\subsubsection{Analytic methods}

- TEAC (Trolox Equivalent Antioxidant Capacity) assay: Radical cation $\left(\mathrm{ABTS}^{\circ+}\right)$ scavenging activity

The free radical scavenging activity of foods was determined by ABTS radical cation decolorization assay (Re et al., 1999) with minor modifications. The method is based on the ability of antioxidant molecules to quench the blue green chromophore with a characteristic absorption of $734 \mathrm{~nm}$, as compared with Trolox, a water-soluble vitamin $\mathrm{E}$ analogue. The addition of antioxidants to the preformed radical cation reduces it to ABTS, determining a decolorization. A stable stock solution of $\left(\mathrm{ABTS}^{\circ+}\right)$ was produced by reacting a $7 \mathrm{mmol} / \mathrm{L}$ aqueous solution of ABTS with $2.45 \mathrm{mmol} / \mathrm{L}$ potassium persulfate. The solution was stored in the dark at room temperature for $12-16 \mathrm{~h}$ before use.

For the study of food samples, the $\mathrm{ABTS}^{+}$solution was diluted with ethanol to an absorbance of $0.70( \pm 0.02)$ at $734 \mathrm{~nm}$ then balanced at $30^{\circ} \mathrm{C}$. After the addition of $1.0 \mathrm{ml}$ of diluted $\left(\mathrm{ABTS}^{\circ+}\right)$ solution to $20 \mu 1$ of food extract or standard Trolox (final concentration $0-15 \mu \mathrm{M}$ ) in ethanol, the absorbance reading was taken at $30^{\circ} \mathrm{C}$, exactly $1 \mathrm{~min}$ after initial mixing $\left(\mathrm{A}_{0}\right)$ and again at $15 \mathrm{~min}\left(\mathrm{~A}_{\mathrm{t}}\right)$. The inhibition percentage of absorbance at $734 \mathrm{~nm}$ was calculated between $A_{0}$ and $A_{t}$, according to the equation: percentage of inhibition $=\left(A_{0}-A_{t}\right) / A_{t}$ with $A_{0}$ as initial optical density and $A_{t}$ as final optical density. Appropriate solvent blanks were run in each assay. All determinations were carried out at least three times. The data presented are an average of three measurements. The intra and inter-assay coefficients were $2.1 \%$ and $3.3 \%$ respectively.

- Total phenol contents (TPC)

The TPC of food extracts were determined using the Folin-Ciocalteu reagent assay (Singleton et al., 1998) with Gallic acid (GA) as a standard. The absorbance was measured at $660 \mathrm{~nm}$. The TPC was expressed in GA equivalents (mg of Gallic acid equivalents per $100 \mathrm{~g}$ of fresh sample) through the calibration curve of GA. All values expressed are a mean of the three replicates. The intra and inter-assay coefficients were $1 \%$ and $5.3 \%$ respectively.

\subsection{Effect of the combination of different foods on total antioxidant capacity and phenol content}

Combinations of two or three different types of basic foods were used to evaluate the effect of mixtures on total antioxidant capacity and phenol content. The estimated antioxidant capacity and that measured in the mixtures were compared. Estimated antioxidant capacity and phenol content of the mixture represented the "mathematical" sum of antioxidant capacities and phenol contents of the different foods of the mixture. Measured antioxidant capacity and phenol content represented the total antioxidant activity and phenol content measured in the mixture.

Mix 1 is a mixture of pie and parsley. Mix 2 is a mixture of fish, sauce and vegetables.

\subsection{Effect on storage and reheating}

To evaluate whether storage can affect TEAC and TPC on a tart/pie, 2 parameters were measured at different consumption times. The convenience foods can be stored for 28 days after manufacturing, the storage conditions are without light and oxygen (heat packed in hermetic packaging), at a temperature of $4^{\circ} \mathrm{C}$. We measured TEAC and TPC at days $9,13,15,16$ and 23 days after manufacturing. The $13^{\text {th }}, 15^{\text {th }}$, and $16^{\text {th }}$ days cover times at which the food is the most likely to be consumed, the $9^{\text {th }}$ represents the shortest conservation and the $23^{\text {rd }}$ represents the sell-by date. The effect of preserving on the properties (antioxidant activity and phenol content) of the food matrix was analyzed on one tart.

To determine whether reheating at home can affect the TEAC and TPC, the 2 parameters were measured for five complex dishes before and after reheating. The dishes are stored in their packaging at $4^{\circ} \mathrm{C}$ during 9 days. They were prepared using the method the most used by consumers to reheat dishes: the microwaving ( $700 \mathrm{~W}, 3$ minutes).

\subsection{Statistical analysis}

Statistical analysis was performed using the freeware R 2.11.0. The differences between samples were analysed using the Student's $t$-test or analysis of variance for more than two samples. They were considered significant at $P$ $<0.05$. All experiments were repeated at least three times. Standard deviations are given in tables and represented as error bars on figures. 


\section{Results and Discussion}

\subsection{Database on the TEAC and the TPC of basic foods}

In this study, the Total Phenol Content (TPC) and the Trolox Equivalent Antioxidant Capacity (TEAC) of 9 basic foods were studied, as shown in table 1 . These results indicated that the mean values of phenols ranged from $41.37 \pm 3.80$ for tomato to $368.89 \pm 8.69 \mathrm{mg}$ gallic acid/100g for fresh parsley.

\section{(Table 1)}

For the total antioxidant activity of basic foods, determined by TEAC assays, the mean values ranged from $2.05 \pm 0.13$ for tomato to $19.00 \pm 0.15 \mu \mathrm{mol}$ trolox/g for fresh parsley. The comparison of these results to the literature data shows that there is variability between the measurements of TEAC and TPC. To illustrate this variability, examples of red wine and onion are taken. For red wines, some authors found total phenol content between 172.4 and $182.7 \pm 8 \mathrm{mg}$ gallic acid/100g and an antioxidant activity between 42.9 and $50 \pm 4 \mu \mathrm{mol}$ trolox/g (Paixao et al., 2007) whereas others found for total phenol content between 101 and $326 \pm 80$ and for antioxidant activity between 7.9 and $24.2 \pm 0.8$ (Seruga et al., 2011). Results depend on the type of wine and winemaking technologies. For onions, the mean antioxidant activity of all the onion samples analyzed was $0.579 \pm 0.304 \mu \mathrm{mol} / \mathrm{g}$, ranging between $0.349 \pm 0.084 \mu \mathrm{mol} / \mathrm{g}$ for the cultivar San Juan de la Rambla and $0.696 \pm 0.371 \mu \mathrm{mol} / \mathrm{g}$ for the Guayonje cultivar (Lorenzo León et al., 2009). The reasons to explain these differences are that vegetables or fruits are different according to the cultivar, the cultivation method and also to methods used for extraction and measurement of phenols or antioxidant molecules.

\subsection{Effect of the combination of different foods on antioxidant capacity and phenol content}

To verify interactions between antioxidant compounds and the food matrix, the antioxidant activity (TEAC) and phenol content (TPC) of various foods have been studied separately and in mixtures to mimic food formulation. Figure 1 shows the evolution of the TPC and the TEAC measured and estimated, for the 2 mixtures studied.

(Figure 1)

Details are given on the first mix which is composed of fresh parsley and fresh pie. Individual TEAC are $13.3 \mu \mathrm{mol}$ trolox for 1 gram of fresh parsley and $21.5 \mu \mathrm{mol}$ trolox for 25 grams of fresh pie. Thus estimated TEAC of the mix is $34.8 \mu \mathrm{mol}$ trolox for $26 \mathrm{~g}$ of mix. The measured TEAC is $24.1 \mu \mathrm{mol}$ trolox for $26 \mathrm{~g}$, a significant difference of $31 \%$ is noticed.

Individual TPC are $3.7 \mathrm{mg}$ gallic acid for 1 gram of fresh parsley and $5.4 \mathrm{mg}$ gallic acid for $25 \mathrm{~g}$ fresh pie, thus estimated TPC of the mix is $9.3 \mathrm{mg}$ gallic acid for $26 \mathrm{~g}$ of mix. The measured TPC is $8.8 \mathrm{mg}$ gallic acid for $26 \mathrm{~g}$ of mix, the difference is not significant.

For the two mixtures, there is a significant difference between the TEAC measured and estimated $(\mathrm{P}<0.05)$, but not between the TPC measured and estimated $(\mathrm{P}>0.05)$. The measured TEAC of mixtures is inferior to the sum of antioxidant capacities of individual ingredients, while the measured TPC are identical. The results can be explained by possible synergic effects. The antioxidant activity of a complex dish cannot be predicted from the antioxidant activity of the ingredients. The masking of the total antioxidant activity is defined as a percentage difference between the measured increase in antioxidant capacity due to the addition of an antioxidant compared to the calculated increase based on an additive effect (Arts et al., 2001).

The total antioxidant activity measured was lower (31\% in the combination of two ingredients (mix 1) and $14 \%$ in the combination of three ingredients ( $\mathrm{mix} 2$ )), than the accumulated antioxidant activities of individual ingredients at the known concentration. Conversely, the total phenol content of mixtures was almost equal to the sum of phenol content of separate ingredients.

The antioxidant activity of the polyphenols being due to their capacity to give up hydrogen, the availability of the hydroxyl groups depends on their chemical and spatial structures. The presence of the food matrix can modify the accessibility of the active group and thus the ability to react of molecules (Pinelo et al., 2004). It seems that the total antioxidant activity cannot be predicted only from the raw materials and that it is necessary to determine this experimentally, while the phenolic content concentration of each ingredient could be estimated in complex systems.

Our results, in complex food matrix, contradict the results found for individual phenolic mixtures. Authors (Heo et al., 2007) found that the total antioxidant activity in the phenolic mixture was equal to the sum of the antioxidant activity of its individual phenolics. However, our results confirm those of Pinelo et al. (2004) who showed that the addition of a new polyphenol to a complex phenolic system does not always promote a positive effect on its overall 
antioxidant activity. Events, which mainly take place when different food matrixes are mixed together, have almost unpredictable consequences on the overall antioxidant properties and food stability (Nicoli et al., 1999).

In conclusion, the only way to know the implications of the addition of a new ingredient with high antioxidant activity is a specific experimental study of the mixture considered. In addition, from a nutritional point of view, the understanding of the consequence of food processing on food composition is one of the most important steps towards a reliable interpretation and evaluation of study results regarding dietary habits and human health.

\subsection{Database on the TEAC and the TPC of convenience foods}

Data of antioxidant capacity and the phenol content of 26 convenience foods were determined and are summarized in Table 2.

\section{(Table 2)}

The analysis of these data shows variations in the content of antioxidants and phenols in different types of dishes, TEAC ranged from $0.77 \pm 0.02$ for "Rigatoni with tomatoes and beef " to $2.34 \pm 0.11 \mu \mathrm{mol}$ trolox per gram of sample for "Greek-style cooked fish with rice" and TPC ranged from $32.27 \pm 2.80$ for "Cod with lemon sauce and rice" to $99.84 \pm 6.65 \mathrm{mg}$ gallic acid per 100 grams of sample for "Provence- style cooked Aubergines with corn semolina". No differences are noticed between fresh dishes and frozen dishes, the frozen step would not lead to a loss of antioxidant activity, for example TEAC for Andalusia-style cooked fish with rice is 1.38 and for frozen paella 1.88 .

The dishes containing the highest antioxidant activity and phenol content are Greek-style cooked fish, Provence-style cooked aubergines and Indian-style cooked courgettes. These results can be explained by the fact that such dishes contain a majority of vegetables in their recipe, as shown in Annex Materials. Greek-style cooked fish has the highest antioxidant activity and phenol content. This is not surprising as this dish is rich in vegetables (aubergines, potatoes, tomatoes, onions, artichokes) and contains spices (coriander, turmeric and paprika). Vegetables, spices and herbs are well-known for their high antioxidant activity.

We also observe that chicken in mustard sauce has a higher antioxidant activity than dried tomatoes in oil with basil and rice, although this dish contains fewer vegetables. Chicken in mustard sauce contains only $3 \%$ mustard and $8 \%$ carrot, whereas the dish based on dried tomatoes contains $53 \%$ of tomatoes, broccoli, carrots, chickpeas, and sweet pepper. Mustard brings a concentration of antioxidant compounds which has a higher activity than vegetables. This result shows that we did not merely consider vegetables in our approach to antioxidant content, and that condiments can also have a high antioxidant activity. Where deep-frozen dishes are concerned, those based on potatoes have a higher antioxidant capacity than dishes based on pasta and rice with the exception of paella. This result corresponds to the high antioxidant activity and phenol content of potatoes compared with pasta and rice (Halvorsen et al., 2002). Tarts vary only slightly, the garnish apparently having only a slight impact on TEAC and TPC. However, the three tarts which have the highest antioxidant activity are composed of vegetables: tomatoes and spinach.

We observed much smaller variations between the TEAC of convenience foods (from $0.77 \pm 0.01$ to $2.34 \pm 0.11 \mu \mathrm{mol}$ trolox equivalents) than in that of more basic foods (from $2.05 \pm 0.02$ to $19.00 \pm 0.15 \mu \mathrm{mol}$ trolox), even though there was a great variation in the composition of the recipes studied. Moreover values of TEAC are higher for basic foods than for convenience foods. This can be explained by different interaction phenomena in the food mixture, which leads to a decrease of the antioxidant activity of the product (Wang et al., 2000). Thus, it is difficult to predict the antioxidant activity of food mixtures when only the antioxidant activity of their ingredients is considered.

Our findings suggest that whole diets ought to be considered when addressing the role of dietary antioxidants in health. Studies of only individual ingredients may underestimate or overestimate the TEAC consumed (Saura-Calixto and Goni, 2006). There is growing scientific evidence that dietary antioxidants may be a critical mediator of the beneficial effects of the Mediterranean Diet (Trichopoulou and Lagiou, 1997). Saura-Calixto and Goni (2006) determined the total dietary antioxidant capacity of a Spanish Mediterranean diet using the same methods. The results obtained were $3549 \mu \mathrm{mol}$ trolox with the ABTS method, and $1171 \mathrm{mg}$ gallic acid/person/day with the Folin-Ciocalteu method. In this diet, the consumption of fruit, vegetables, and cereals represents only 782 $\mu \mathrm{mol}$ trolox equivalents and $502 \mathrm{mg}$ of gallic acid. For instance, Greek-style fish cooked can provide $702 \mu \mathrm{mol}$ trolox equivalents per serving and $263 \mathrm{mg}$ gallic acid which represents a major part of estimated TEAC. Individual foods known to have a high antioxidant capacity per gram (for instance parsley) may contribute very little to the antioxidant activity of a whole diet. 
Two factors should not be neglected: (i) Much is known about the properties of each antioxidant, but there is only limited data on intakes of antioxidant mixtures. Interactions between ingredients have an impact on their antioxidant properties. (ii)The influence of food processing on naturally occurring antioxidants is a key factor in finding those technological conditions necessary to preserve or improve their original activity

\subsection{Effect of culinary reheating and storage}

\subsubsection{Effect of reheating}

The effect of reheating by microwave was studied on five complex dishes by measuring the TPC and the TEAC. Results are shown in Figures 2 and 3. There is no significant difference between values before and after reheating for Mixes 2, 3, 4 and $5(\mathrm{P}>0.05)$, but there is a significant difference for Mix $1(\mathrm{P}<0.05)$.

\section{(Figure 2)}

As can be seen on figure 2, TEAC of mixture 1 (Provence-style-cooked aubergines with corn semolina) decreased, which can be explained by a loss of natural antioxidants (carotenoids, ascorbic acid, polyphenols, etc) or may be due to the formation of novel compounds having pro-antioxidant activity (i.e. Maillard reaction products). The results observed for the other 4 dishes can be explained by a balancing of the simultaneous formation of compounds with novel or improved antioxidant properties (for instance Maillard reaction products). The great variety and complexity of compounds present in food matrixes (other antioxidants and polyphenols, oxidative enzymes, metals, etc) make it impossible to carry out an exhaustive study of their reactivity and their consequences (Pinelo et al., 2004).

\section{(Figure 3)}

On figure 3, we notice an increase of phenol content, which can be explained by a concentration of material due to thermal heating. In light of these considerations, the changes in the overall antioxidant properties of food can be attributed to the sum of the different and sometimes opposing events previously mentioned. Authors (Lo Scalzo et al., 2004) obtained the same conclusions with orange juices-thermal treatment led to an increase of phenol compounds due to the polymerisation of phenols and the liberation of bound phenols, and a decrease of antioxidant activity due to a high loss in ascorbic acid.

\subsubsection{Effect of storage}

The effect of storage on a savoury pie was studied by measuring the TPC and the TEAC at different consumption times. We observed no effect on these two parameters during storage $(\mathrm{P}>0.05)$. Similar observations were previously made on some fruits and vegetables stored at room temperature or in the refrigerator. The result of the study by Kevers et al. (2007) indicated that in most fruits and vegetables, storage did not negatively affect the antioxidant capacity. In contrast, Nicoli et al. (2000) reported an increase of more than $50 \%$ of the initial antiradical activity of a catechin solution during the first 2 days of storage at $25^{\circ} \mathrm{C}$. In only a few cases the antioxidant capacity decreased during storage. In apricots for instance, a decrease in the antioxidant activity during storage was observed at low temperatures (Bartolini et al., 2006). Storage times can promote or enhance the progressive enzymatic or chemical oxidation of phenolic compounds. These reactions proceed at different rates depending on some intrinsic food variables as well as on processing conditions $\left(\mathrm{a}_{\mathrm{w}}, \mathrm{pH}\right.$, time, temperature, oxygen availability, etc).

The antioxidant potential of a polyphenol-containing food can vary greatly depending on its history or, at least, on when it is consumed (Nicoli et al., 1999).

\section{Conclusion}

Functional foods, beneficial for consumers, must keep a high antioxidant activity despite the phenomena undergone before consumption. Among the phenomena studied (formulation, reheating, storage), the step of formulation leads to a great loss of antioxidant activity. A database on antioxidant activity of basic and convenience foods, often consumed by the French population, has been constituted. We noticed that convenience foods having the higher TEAC are not automatically the dishes based mainly on vegetables, as condiments also have an important contribution. Moreover, TEAC of convenience foods $(0.77 \pm 0.01$ to $2.34 \pm 0.11 \mu$ mol trolox equivalents) are lower than TEAC of basic foods (from $2.05 \pm 0.02$ to $19.00 \pm 0.15 \mu$ mol trolox). Nevertheless, a comparison with the data in the literature was problematic due to the lack of standardization of the products and assays used.

The findings of this study suggest that we can predict the TPC of a food mixture from the TPC of their ingredients. The mechanisms are more complex with the antioxidant activity due to many interactions between antioxidant 
compounds and/or with the food matrix. Values measured of antioxidant capacity were slightly lower than expected values- between 14 and $31 \%$ depending on the number of mixture ingredients.

Methods of reheating and storage have no effect on the TPC and TEAC of foods studied. In the literature, many contradictory results can be found concerning the evolution of the antioxidant activity during food processes. This disagreement is essentially due to the behaviour of antioxidant compounds which is different according to the situation: process conditions, food matrix, and presence of other antioxidant compounds. Indeed, the study of a single antioxidant may be of limited value because the possible interaction in a food mixture is not taken into account.

Determining the total antioxidant capacity of convenience foods is particularly representative of contemporary dietary studies. However, the determination of each antioxidant compound is not sufficient when determining the beneficial potential of antioxidants. Thus, to develop knowledge about the prediction of antioxidant properties, further studies will have to deal with the understanding of interactions between antioxidant compounds and other ingredients, in order to develop a prediction tool of the antioxidant activity of complex foods.

\section{References}

Arts, M. J. T. J., Haenen, G. R. M. M., Voss, H.-P., \& Bast, A. (2001). Masking of antioxidant capacity by the interaction of flavonoïds with protein. Food and Chemical Toxicology, 39 (8), 787-791. http://dx.doi.org/10.1016/S0278-6915(01)00020-5

Bartolini, S., Zanol, G. C., \& Viti, R. (2006). Apricot cultivars and cold storage affect the total antioxidant capacity and glutathione content in fruit. Acta Horticulturae, 717, 359-362.

Diplock, A. T., Aggett, P. J., Ashwell, M., Bornet, F., Fern, E. B., \& Roberfroid, M. B. (1999). Scientific Concepts of Functional foods in Europe: Consensus document. British Journal of Nutrition, 81, I-S27.

Halvorsen, B. L., Holte, K., Myhrstad, M. C. W., Barikmo, I., Hvattum, E., Remberg, S. F., Wold, A. B., Haffner, K., Baugerød, H., Andersen, L. F., Moskaug, J. Ø., Jacobs, Jr D. R., \& Blomhoff, R. (2002). A systematic screening of total antioxidants in dietary plants. Journal of Nutrition, 132, 461-471.

Heo, H. J., Kim, Y. J., Chung, D., \& Kim, D. O. (2007). Antioxidant capacities of individual and combined phenolics in a model system. Food Chemistry, 104, 87-92. http://dx.doi.org/10.1016/j.foodchem.2006.11.002

Igual, M., García-Martínez, E., Camacho, M. M., \& Martínez-Navarrete, N. (2010). Effect of thermal treatment and storage on the stability of organic acids and the functional value of grapefruit juice. Food Chemistry, 118, 291-299. http://dx.doi/10.1016/j.foodchem.2009.04.118

Kevers, C., Falkowski, M., Tabart, J., Defraigne, J. O., Dommes, J., \& Pincemail, J. (2007). Evolution of antioxidant capacity during storage of selected fruits and vegetables. Journal of Agricultural and Food Chemistry, 55, 8596-8603. http://dx.doi.org/10.1021/jf071736j

Lo Scalzo, R., Iannoccari, T., Summa, C., Morelli, R., \& Rapisarda, P. (2004). Effect of thermal treatments on antioxidant and antiradical activity of blood orange juice. Food Chemistry, 85, 41-47. http://dx.doi.org/10.1016/j.foodchem.2003.05.005

Lorenzo León, H. C., Rodríguez Gáldon, B., Rodríguez Rodríguez, E. M., \& Díaz Romero, C. (2009). Antioxidant capacity of different onion cultivars. Ciencia $y$ tecnologia alimentaria, 1, 53-58. http://dx.doi.org/10.1080/11358120902850784

Menezes, E. W., Gonçalves, F. A., Giuntini, E. B., \& Lajolo, F. M. (2002). Food composition database for bioactive food components. Journal of Food composition and Analysis, 15 (4), 419-434. http://dx.doi.org/10.1006/jfca.2002.1073

Moure, A., Cruz, J. M., Franco, D., Dominguez, J. M., Sineiro, J., Dominguez, H., Nùňez, M. J., \& Parajó, J. C. (2001). Natural antioxidants from residual sources. Food Chemistry, 72, 145-171. http://dx.doi.org/10.1016/S0308-8146(00)00223-5

Murakami, M., Yamaguchi, T., Takamura, H., \& Matoba, T. (2004). Effects of Thermal Treatment on Radical-Scavenging Activity of Single and Mixed Polyphenolic Compounds. Food Chemistry and Toxicology, 9 (1), FCT7-10. http://dx.doi.org/10.1111/j.1365-2621.2004.tb17848.x

Nicoli, M. C., Anese, M., \& Parpinel, M. (1999). Influence of processing on the antioxidant properties of fruit and vegetables. Trends in Food Science and Technology, 10, 94-100. http://dx.doi.org/10.1016/S0924-2244(99)00023-0 
Nicoli, M. C., Calligaris, S., \& Manzocco, L. (2000). Effect of enzymatic and chemical oxidation on the antioxidant capacity of catechin model systems and apple derivatives. Journal of Agricultural and Food Chemistry, 48, 4576-4580. http://dx.doi.org/10.1021/jf0001511

Olsson, M. E., Gustavsson, K. E., \& Vagen, I. (2010). Quercetin and Isorhamnetin in Sweet and Red Cultivars of Onion at Harvest, after Field Curing, Heat Treatment and Storage. Journal of Agricultural of Food Chemistry, 58, 2323-2330. http://dx.doi.org/10.1021/jf9027014

Paixao, N., Perestrelo, R., Marques, J. C., \& Camara, J. S. (2007). Relationship between antioxidant capacity and total phenolic content of red, rosé and white wines. Food Chemistry, 105, 204-214. http://dx.doi.org/10.1016/j.foodchem.2007.04.017

Pellegrini, N., Serafini, M., Colombi, B., Del Rio, D., Salvatore, S., Bianchi, M., \& Brighenti, F. (2003). Total antioxidant capacity of plant foods, beverages and oils consumed in Italy assessed by three different in vitro assays. Journal of Nutrition, 133, 2812-2819.

Philpott, M., Gould, K. S., Lim, C., \& Ferguson, L. R. (2004). In Situ and In Vitro Antioxidant Activity of Sweetpotato Anthocyanins. Journal of Agricultural and Food Chemistry, 52, 1511-1513. http:dx.doi.org/10.1021/jf034593j

Pinelo, M., Manzocco, L., Nunez, M. J., \& Nicoli, M. C. (2004). Interaction among Phenols in Food Fortification: Negative Synergism on Antioxidant Capacity. Journal of Agricultural and Food Chemistry, 52, 1177-1180. http://dx.doi.org/10.1021/jf0350515

Price, K. R., Bacon, J. R., \& Rhodes, M. J. C. (1997). Effect of storage and domestic processing on the content and composition of flavonols glucosides in onion (Allium cepa). Journal of Agricultural and Food Chemistry, 45, 938-942. http://dx.doi.org/10.1021/jf9605916

Proteggente, A. R., Pannala, A. S., Paganga, G., et al. (2002). The antioxidant activity of regularly consumed fruit and vegetables reflects their phenolic and vitamin C composition. Free Radical Research, 36, 217-233. http:dx.doi.org/10.1080/10715760290006484

Re, R., Pellegrini, N., Proteggente, A., Pannala, A., Yang, M., \& Rice-Evans, C. (1999). Antioxidant activity applying an improved ABTS radical cation decolorization assay. Free Radical Biology and Medicine, 26, 1231-1237. http://dx.doi.org/10.1016/S0891-5849(98)00315-3

Saura-Calixto, F., \& Goni, I. (2006). Antioxidant capacity of the Spanish Mediterranean diet. Food Chemistry, 94 , 442-447. http://dx.doi.org//10.1016/j.foodchem.2004.11.033

Seruga, M., Novak, I., \& Jakobek, L. (2011). Determination of polyphenols content and antioxidant activity of some red wines by differential pulse voltammetry, HPLC and spectrophotometric methods. Food Chemistry, 124, 1208-1216. http:dx.doi.org/10.1016/j.foodchem.2010.07.047

Singleton, V. L., Orthofer, R., \& Lamuela-Raventos, R. M. (1998). Analysis of total phenols and other oxidation substrates and antioxidants by means of folin-ciocalteu reagent. Methods in Enzymology, 299, 152-178. http://dx.doi.org/10.1016/S0076-6879(99)99017-1

Stahl, S., Miller, K. B., Apgar, J., et al. (2009). Preservation of Cocoa Antioxidant Activity, Total Polyphenols, Flavan-3-ols, and Procyanidin Content in Foods Prepared with Cocoa Powder. Journal of food Science, 74 (6), C456-461. http:dx.doi.org/10.1111/j.1750-3841.2009.01226.x

Tudela, J. A., Cantos, E., Espin, J. C., Tomas-Barberan, F. A., \& Gil, M. I. (2002). Induction of Antioxidant Flavonol Biosynthesis in Fresh-cut Potatoes.Effect of Domestic Cooking. Journal of Agricultural and Food Chemistry, 50, 5925-5931. http://dx.doi.org/10.1021/jf020330y

Trichopoulou, A., \& Lagiou, P. (1997). Healthy traditional Mediterranean diet: An expression of culture, history, and lifestyle. Nutrition Reviews, 55, 383-389. http://dx.doi.org/10.1111/j.1753-4887.1997.tb01578.x

Viña, S Z, \& Chaves, A. R. (2007). Respiratory activity and phenolic compounds in pre-cut celery. Food chemistry, 100 (4), 1654-1660. http://dx.doi.org/10.1016/j.foodchem.2005.12.060

Volden, J., Borge, A. I. G., Bengtsson, B. G., Hansen, M., Thygesen, E. I., \& Wicklund, T. (2008). Effect of thermal treatment on glucosinolates and antioxidant-related parameters in red cabbage (Brassica oleracea L. ssp. capitata f. rubra). Food Chemistry, 109, 595-165. http://dx.doi.org/10.1016/j.foodchem.2008.01.010

Wang, W., Weng, X., \& Cheng, D. (2000). Antioxidant activities of natural phenolic components from Dalbergia odorifera T. Chen. Food Chemistry, 71, 45-49. http://dx.doi.org/10.1016/S0308-8146(00)00123-0 
Zhou, K., \& Yu, L. (2006). Total phenolic contents and antioxidant properties of commonly consumed vegetables grown in Colorado. Food Science and Technology, 39, 1155-1162. http:dx.doi.org/10.1016/j.lwt.2005.07.015

Annex Materials. Description of 26convenience foods

\begin{tabular}{|c|c|c|}
\hline Type & $\begin{array}{l}\text { Name of the } \\
\text { recipe }\end{array}$ & Recipe * \\
\hline \multirow{12}{*}{ 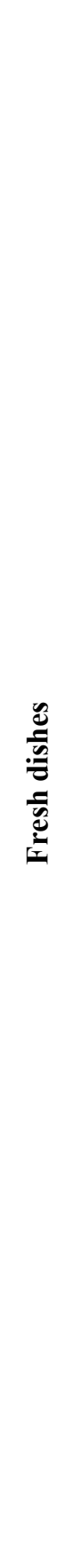 } & $\begin{array}{l}\text { Greek-style } \\
\text { cooked fish } \\
\text { with rice }\end{array}$ & $\begin{array}{l}\text { Eggplants } 23.5 \% \text {. potatoes } 20 \% \text {. white fish } 19 \% \text {.tomatoes } 8 \% \text {. water. onions. ewe's milk } \\
\text { cheese } 4 \% \text {. artichokes. tomato puree. olives } 1.5 \% \text {. garlic. raisins. coriander. modified } \\
\text { starch. olive oil. salt. sugar. sweet pepper and dried tomatoes. spices (turmeric and } \\
\text { paprika) and flavouring. }\end{array}$ \\
\hline & $\begin{array}{l}\text { Provence- style } \\
\text { cooked } \\
\text { Eggplants with } \\
\text { corn semolina }\end{array}$ & $\begin{array}{l}\text { Tomatoes } 27 \% \text {. corn semolina } 14.5 \% \text {. water. aubergines French fries (of sunflower oil) } \\
7 \% \text {. aubergines } 7 \% \text {.sweet pepper } 6.5 \% \text {. onion. courgettes } 4 \% \text {. carrots } 3 \% \text {. raisins. tomato } \\
\text { puree. olive oil. garlic paste. salt. basil. sugar. modified starch. flavouring. thyme. pepper. }\end{array}$ \\
\hline & $\begin{array}{l}\text { Indian-style } \\
\text { cooked } \\
\text { zucchinis with } \\
\text { rice }\end{array}$ & $\begin{array}{l}\text { Courgettes } 34 \% \text {. cooked rice } 19.5 \% \text {. water. fresh cream. carrots. chilli pepper. tomato } \\
\text { puree. peas. boiled wild rice } 1.3 \% \text {. twists of lemon } 1 \% \text {. curry. flavouring. chive. olive oil. } \\
\text { coriander. salt. garlic. cumin. modified starch. }\end{array}$ \\
\hline & $\begin{array}{l}\text { Chicken in } \\
\text { mustard sauce } \\
\text { with rice }\end{array}$ & $\begin{array}{l}\text { White rice } 30 \% \text {.chicken } 25.5 \% \text {. water. carrots } 8 \% \text {. fresh cream. shallots. Dijon mustard } \\
3 \% \text {. peas } 3 \% \text {. Sunflower oil. white wine. wild rice } 1 \% \text {. vinegar. salt. wholegrain mustard } \\
0.3 \% \text {. natural aromas. modified starch. }\end{array}$ \\
\hline & $\begin{array}{l}\text { Dried tomatoes } \\
\text { with basil and } \\
\text { rice }\end{array}$ & $\begin{array}{l}\text { White rice } 27 \% \text {. tomatoes } 25 \% \text {. broccoli } 7.5 \% \text {. carrots } 6.5 \% \text {. dried tomatoes } 6.5 \% \text {. water. } \\
\text { chickpeas } 4.5 \% \text {. sweet pepper } 3 \% \text {. tomato puree. black olives. sugar. parmesan. olive oil. } \\
\text { garlic. basil. salt. tarragon. flavouring. modified starch. dextrose. pepper. }\end{array}$ \\
\hline & $\begin{array}{l}\text { Andalusia-style } \\
\text { cooked fish } \\
\text { with rice }\end{array}$ & $\begin{array}{l}\text { White rice } 34 \% \text {. courgettes } 23.5 \% \text {. white fish } 19 \% \text {. sweet pepper } 8.5 \% \text {. green peas. fried } \\
\text { onion (sunflower oil) olive oil. tomato puree. natural flavouring. garlic. salt. spices } \\
\text { (turmeric. saffron). flavouring. modified starch. chilli pepper and dried tomatoes. wheat. } \\
\text { pepper. }\end{array}$ \\
\hline & $\begin{array}{l}\text { Minced beef } \\
\text { and mashed } \\
\text { potatoes gratin }\end{array}$ & $\begin{array}{l}\text { Tashed potatoes } 65 \% \text {. water. cooked beef } 8.5 \% \text {. onions } 2.5 \% \text {. carrots. chicken stock. } \\
\text { todified starch. chives. garlic. salt. thickener: Xanthane gum. natural pepper extract. }\end{array}$ \\
\hline & $\begin{array}{l}\text { Italian-style } \\
\text { cooked fish }\end{array}$ & $\begin{array}{l}\text { Pasta } 48 \% \text {. white fish } 19 \% \text {. tomatoes } 12 \% \text {. water. courgettes. shallots. tomatoes } 1.5 \% \text {. } \\
\text { carrots. olive oil. Parmesan } 1 \% \text {. garlic. tomato puree. black olives. modified starch. salt. } \\
\text { basil } 0.3 \% \text {. dehydrated sweet pepper. spices and herbs/flavourings. palm oil. vinegar. } \\
\text { sugar. pepper. }\end{array}$ \\
\hline & $\begin{array}{l}\text { Lasagna } \\
\text { bolognaise }\end{array}$ & $\begin{array}{l}\text { Water. lasagna } 20 \% \text {. cooked beef } 11 \% \text {. tomato puree. onions } 3.5 \% \text {. carrots. low fat fresh } \\
\text { cream. modified starch. sunflower oil. basil } 0.8 \% \text {. corn flour. celery. flavouring. sugar. } \\
\text { lactose and milk proteins - cream. salt. garlic. natural extracts: nutmeg - pepper - clove - } \\
\text { thyme. }\end{array}$ \\
\hline & $\begin{array}{l}\text { Gratin } \\
\text { dauphinois }\end{array}$ & $\begin{array}{l}\text { Water. potatoes } 44 \% \text {. fresh cream. ham } 7.5 \% \text {. cheese } 13 \% \text {. modified starch. salt. natural } \\
\text { extracts of pepper and nutmeg. }\end{array}$ \\
\hline & $\begin{array}{l}\text { Quenelles of } \\
\text { pike with rice }\end{array}$ & $\begin{array}{l}\text { Pike quenelles } 26.5 \% \text {. white rice } 21 \% \text {. water. tomatoes } 12.5 \% \text {. carrot puree } 7 \% \text {. } \\
\text { courgettes } 4.5 \% \text {. carrots } 4.5 \% \text {. shallots. sunflower oil. tomato puree. olive oil. flavours } \\
\text { (milk. celery). modified starch. Sherry vinegar } 0.3 \% \text {. garlic. sugar. chicken stock. } \\
\text { flavourings. pepper. }\end{array}$ \\
\hline & $\begin{array}{l}\text { Cod with } \\
\text { lemon sauce } \\
\text { and rice }\end{array}$ & $\begin{array}{l}\text { Cod } 31 \% \text {. cooked basmati rice } 29.5 \% \text {. carrots } 12 \% \text {. water. fresh cream. sunflower oil. } \\
\text { broccoli } 2 \% \text {. shallots. lemon juice and peel } 1.3 \% \text {. salt. modified starch. sugar. natural } \\
\text { flavours (shellfish. celery). turmeric. }\end{array}$ \\
\hline \multirow{2}{*}{ 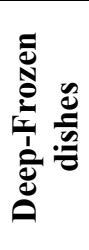 } & $\begin{array}{l}\text { Savoy-style } \\
\text { cooked } \\
\text { potatoes }\end{array}$ & $\begin{array}{l}\text { Potatoes fried } 44 \% \text { (potatoes. vegetable oil). water. onions. cheese } 8 \% \text {. white cheese. } \\
\text { bacon } 5 \% \text {. mozzarella. low fat fresh cream. modified starch. flavouring. salt. thickener: } \\
\text { Xanthane gum. natural pepper extract. }\end{array}$ \\
\hline & Paella & $\begin{array}{l}\text { Saffron rice } 46.5 \% \text { (rice. turmeric). water. cooked chicken } 9.5 \% \text {. shrimps } 6 \% \text {. fish } 6 \% \text {. } \\
\text { tomatoes. peas. onions. pepper. chorizo } 1.5 \% \text {. tomato puree. flavouring. salt. paprika. } \\
\text { shrimp extract. }\end{array}$ \\
\hline
\end{tabular}




\begin{tabular}{|c|c|c|}
\hline & $\begin{array}{l}\text { Tuna and } \\
\text { potato gratin }\end{array}$ & $\begin{array}{l}\text { Potatoes fried } 38 \% \text { (potatoes. palm and sunflower oil). tomatoes } 17 \% \text {. tuna } 10 \% \\
\text { (sunflower oil). sweet pepper } 7.5 \% \text {. edam. tomato puree } 6 \% \text {. water. onions. olive oil. } \\
\text { basil. modified starch. garlic. sugar. gelling agent: pectin. salt. dextrose. natural extracts } \\
\text { of pepper and thyme. }\end{array}$ \\
\hline & $\begin{array}{l}\text { Savoy-style } \\
\text { baked gratin }\end{array}$ & $\begin{array}{l}\text { Potatoes fried } 39.5 \% \text { (potatoes. palm and sunflower oil). water. fresh cream } 8 \% \text {. fried } \\
\text { onions } 8 \% \text {. ham } 5.5 \% \text {. emmental cheese } 4 \% \text {. reblochon cheese } 2.5 \% \text {. butter. modified } \\
\text { starch. natural flavouring. lactose and milk proteins - cream. powdered egg white and } \\
\text { yolks. salt. pepper. nutmeg. }\end{array}$ \\
\hline & Basque chicken & $\begin{array}{l}\text { White rice } 42.5 \% \text {. chicken } 13 \% \text {. water. tomatoes } 9 \% \text {.sweet pepper } 8.5 \% \text {. onions. tomato } \\
\text { puree. Sherry vinegar. sunflower oil. garlic. modified starch. salt. basil. natural Cayenne } \\
\text { pepper extracts. }\end{array}$ \\
\hline & $\begin{array}{l}\text { Conchiglie } \\
\text { with tuna }\end{array}$ & $\begin{array}{l}\text { Pasta (conchiglie) } 46 \% \text {. tomato puree. tuna } 11.5 \% \text {. sunflower oil. onions. tomatoes. } \\
\text { olive oil. garlic. sugar. basil. salt. sherry vinegar. black olives } 0.5 \% \text {. modified starch. } \\
\text { oregano. extracted essence of pepper. }\end{array}$ \\
\hline & $\begin{array}{l}\text { Farfallini with } \\
\text { gorgonzola }\end{array}$ & $\begin{array}{l}\text { Pasta ( farfallini) } 50 \% \text {. water. fresh light cream } 13 \% \text {. mushrooms. ham } 9 \% \text {. } \\
\text { Gorgonzola cheese } 1.5 \% \text {. modified starch. basil. salt. yeast extract. colza oil - milk } \\
\text { protein - cream. natural pepper and nutmeg extract. }\end{array}$ \\
\hline & $\begin{array}{l}\text { Rigatoni with } \\
\text { tomatoes and } \\
\text { beef }\end{array}$ & $\begin{array}{l}\text { Pasta (rigatoni) } 48 \% \text {. meat of beef } 14 \% \text {. tomato purees } 11.5 \% \text {. tomatoes } 10 \% \text {. } \\
\text { water. hard cheese } 2.5 \% \text {. onions. olive oil. modified starch. basil. salt. shallots. } \\
\text { sugar. garlic. pepper. }\end{array}$ \\
\hline \multirow{12}{*}{$\stackrel{\infty}{=}$} & \multirow{2}{*}{$\begin{array}{l}\text { Tomatoe and } \\
\text { mozzarella tart }\end{array}$} & Flaky pastry $32 \%$ : corn flour . margarine. water. chicory fibre. salt. L cysteine. \\
\hline & & $\begin{array}{l}\text { Garnish } 68 \% \text { : water. tomatoes } 19 \% \text {. mozzarella } 10.5 \% \text {. mushrooms. ham } 8 \% \text {. } \\
\text { lactose. syrup of glucose. dextrose. natural flavour. eggs. fresh cream. white egg. } \\
\text { modified starch. shallots. skimmed milk powder. olive oil } 1 \% \text {. basil. salt. origan. } \\
\text { natural pepper extract. }\end{array}$ \\
\hline & \multirow{2}{*}{$\begin{array}{l}\text { Goat's milk } \\
\text { cheese and } \\
\text { spinach tart }\end{array}$} & Flaky pastry $39 \%$ : corn flour. margarine. water. salt. L cysteine. \\
\hline & & $\begin{array}{l}\text { Garnish } 61 \% \text { : spinach } 25 \% \text {. soft white cheese. low fat fresh cream. goat's milk } \\
\text { cheese } 11.5 \% \text {. eggs. skimmed milk powder. thickener: E } 1422 \text {. garlic. salt. } \\
\text { sunflower oil. flavouring. cumin. curry. }\end{array}$ \\
\hline & \multirow{2}{*}{$\begin{array}{l}\text { Provencal } \\
\text { tomatoes tart }\end{array}$} & Flaky pastry 39\%: corn flour. margarine. water. chicory fibre. salt. L cysteine. \\
\hline & & $\begin{array}{l}\text { Garnish } 61 \% \text { : tomatoes } 21 \% \text {. water. soft white cheese. zucchinis. onions. eggs. } \\
4.5 \% \text {. white of egg. fresh cream. emmental cheese .dried breadcrumbs. skimmed } \\
\text { milk powder. garlic. modified starch. tomato puree. olive oil . basil } 0.9 \% \text {. parsley } \\
\text { chicory fibre. shallots. Sherry vinegar. salt. natural extracts of pepper and } \\
\text { nutmeg. }\end{array}$ \\
\hline & \multirow[t]{2}{*}{ Leek tart } & Flaky pastry 39\%: corn flour. margarine. water. chicory fibre. salt. L cysteine. \\
\hline & & $\begin{array}{l}\text { Garnish } 61 \% \text { : water. leek } 29 \% \text {. spinach. eggs. white egg. fresh cream. emmental } \\
\text { cheese } 4 \% \text {. shallots. modified starch. egg yolk powder some. chicory fibre. salt. } \\
\text { sunflower oil. natural nutmeg and pepper extracts. }\end{array}$ \\
\hline & \multirow{2}{*}{$\begin{array}{l}\text { Salmon and } \\
\text { sorrel tart }\end{array}$} & Flaky pastry 39\%: corn flour. margarine. water. fibre of chicory. salt. L cysteine. \\
\hline & & $\begin{array}{l}\text { Garnish } 61 \% \text { : water. salmon } 31.5 \% \text {. eggs. fresh cream } 7 \% \text {. white wine. sorrel } \\
3 \% \text {. spinach. modified starch. skimmed milk powder. cream - milk proteins. } \\
\text { chive. natural flavouring. salt. shallots. lemon juice. natural nutmeg and pepper } \\
\text { extracts. }\end{array}$ \\
\hline & \multirow[t]{2}{*}{ St Jacques tart } & Flaky pastry $39 \%$ : corn flour. margarine. water. of chicory fibre. salt. L cysteine. \\
\hline & & $\begin{array}{l}\text { Garnish } 61 \% \text { : water. Saint Jacques } 18 \% \text {. carrots. fresh cream. tomatoes. celery. } \\
\text { white egg. eggs. emmental cheese. skimmed milk powder. vermouth (Noilly Prat) } \\
2.5 \% \text {. modified starch. shallots. parsley. sunflower oil. salt. natural extracts of } \\
\text { pepper and nutmeg. natural flavouring (shellfish) }\end{array}$ \\
\hline
\end{tabular}

* percentages included in the list of ingredients are the ones found on the packaging and are based on wet weight. 
Table 1. The total antioxidant capacity ( $\mu$ mol trolox per gram of fresh weight and per serving size) and the total phenol content (mg gallic acid per 100 grams of fresh weight and per serving size) of 9 basic foods

\begin{tabular}{|l|c|c|}
\hline \multicolumn{1}{|c|}{ Food sample name } & $\begin{array}{c}\text { Total phenol } \\
\text { content } \\
\text { (mg gallic acid } \\
/ 100 \text { g fresh } \\
\text { weight) }\end{array}$ & $\begin{array}{c}\text { Total antioxidant } \\
\text { capacity } \\
\text { ( } \begin{array}{c}\mu \text { mol trolox } / g \\
\text { fresh weight }\end{array}\end{array}$ \\
\hline Olive Oil & & \\
\hline Tomato & $\mathbf{4 1 . 3 7} \pm \mathbf{3 . 8 0}$ & $\mathbf{2 . 0 5} \pm \mathbf{0 . 1 3}$ \\
\hline Onion & $\mathbf{1 5 1 . 6 1} \pm \mathbf{0 . 6 8}$ & $\mathbf{3 . 1 0} \pm \mathbf{0 . 1 9}$ \\
\hline Mustard & $\mathbf{7 1 9 . 3 4} \pm \mathbf{8 . 6 9}$ & $\mathbf{1 0 . 2 7} \pm \mathbf{0 . 2 4}$ \\
\hline Lentils & $\mathbf{6 7 . 5 2} \pm \mathbf{1 . 5 9}$ & $\mathbf{4 . 2 3} \pm \mathbf{0 . 1 0}$ \\
\hline Sweet pepper & $\mathbf{1 0 8 . 9 7} \pm \mathbf{2 . 1 0}$ & $\mathbf{4 . 3 1} \pm \mathbf{0 . 0 4}$ \\
\hline Green olives & $\mathbf{1 1 0 . 7 3} \pm \mathbf{8 . 5 5}$ & $\mathbf{4 . 9 7} \pm \mathbf{0 . 0 3}$ \\
\hline Red wine & $\mathbf{3 3 8 . 5 9} \pm \mathbf{2 9 . 7 2}$ & $\mathbf{2 7 . 3 5} \pm \mathbf{0 . 7 1}$ \\
\hline Parsley & $\mathbf{3 6 8 . 8 9} \pm \mathbf{8 . 6 9}$ & $\mathbf{1 9 . 0 0} \pm \mathbf{0 . 1 5}$ \\
\hline
\end{tabular}


Table 2. The total antioxidant capacity ( $\mu$ mol trolox per gram of fresh weight and per serving size) and the total phenol content (mg gallic acid per 100 grams of fresh weight and per serving size) of 26 convenience foods

\begin{tabular}{|c|c|c|c|c|}
\hline $\begin{array}{l}\text { Type } \\
\text { of } \\
\text { dish }\end{array}$ & & Food sample name & $\begin{array}{l}\text { Total antioxidant } \\
\text { capacity } \\
\text { ( } \mu \text { mol trolox } / \mathrm{g} \\
\text { fresh weight) }\end{array}$ & $\begin{array}{l}\text { Total phenol } \\
\text { content } \\
\text { (mg gallic acid } \\
\text { /100 g fresh } \\
\text { weight) }\end{array}$ \\
\hline \multirow{18}{*}{ 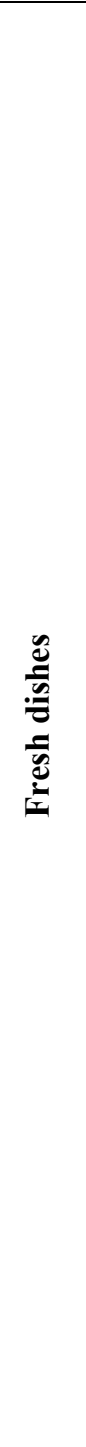 } & \multirow{12}{*}{ 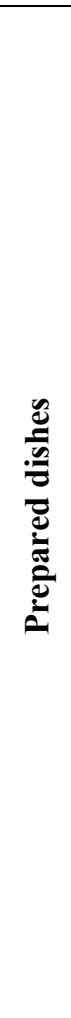 } & $\begin{array}{c}\text { Greek-style cooked fish } \\
\text { with rice }\end{array}$ & $2.34 \pm 0.11$ & $87.73 \pm 12.37$ \\
\hline & & $\begin{array}{l}\text { Provence- style cooked } \\
\text { Eggplants with corn } \\
\text { semolina }\end{array}$ & $2.13 \pm 0.04$ & $99.84 \pm 6.65$ \\
\hline & & $\begin{array}{l}\text { Indian-style cooked } \\
\text { zucchinis with rice }\end{array}$ & $1.94 \pm 0.02$ & $85.09 \pm 3.25$ \\
\hline & & $\begin{array}{l}\text { Chicken in mustard } \\
\text { sauce with rice }\end{array}$ & $1.87 \pm 0.07$ & $69.00 \pm 2.23$ \\
\hline & & $\begin{array}{l}\text { Dried tomatoes with } \\
\text { basil and rice }\end{array}$ & $1.43 \pm 0.10$ & $71.58 \pm 7.23$ \\
\hline & & $\begin{array}{l}\text { Andalusia-style cooked } \\
\text { fish with rice }\end{array}$ & $1.38 \pm 0.07$ & $66.1 \pm 8.34$ \\
\hline & & $\begin{array}{l}\text { Minced beef and } \\
\text { mashed potatoe gratin }\end{array}$ & $1.38 \pm 0.07$ & $52.98 \pm 7.59$ \\
\hline & & Italian-style cooked fish & $1.37 \pm 0.06$ & $54.26 \pm 2.06$ \\
\hline & & Lasagna bolognaise & $1.35 \pm 0.05$ & $51.04 \pm 6.21$ \\
\hline & & Gratin Dauphinois & $1.19 \pm 0.03$ & $61.29 \pm 3.91$ \\
\hline & & $\begin{array}{l}\text { Quenelles of pike with } \\
\text { rice }\end{array}$ & $1.14 \pm 0.08$ & $48.29 \pm 1.84$ \\
\hline & & $\begin{array}{c}\text { Cod with lemon sauce } \\
\text { and rice }\end{array}$ & $0.81 \pm 0.02$ & $32.27 \pm 2.80$ \\
\hline & \multirow{6}{*}{ 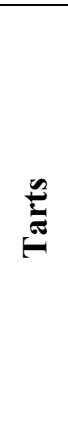 } & $\begin{array}{c}\text { Tomato and mozzarella } \\
\text { tart }\end{array}$ & $1.24 \pm 0.12$ & $34.93 \pm 0.10$ \\
\hline & & $\begin{array}{l}\text { Tart in goat's milk } \\
\text { cheese and spinach }\end{array}$ & $1.19 \pm 0.1$ & $41.81 \pm 2.54$ \\
\hline & & $\begin{array}{l}\text { Goat's milk cheese and } \\
\text { spinach tart }\end{array}$ & $1.14 \pm 0.06$ & $48.00 \pm 1.42$ \\
\hline & & Tart in leeks & $1.13 \pm 0.08$ & $41.19 \pm 1.42$ \\
\hline & & Provencal tomatoes tart & $0.97 \pm 0.09$ & $33.77 \pm 3.82$ \\
\hline & & Tart in St.Jacques & $0.91 \pm 0.07$ & $48.12 \pm 3.63$ \\
\hline \multirow{8}{*}{ 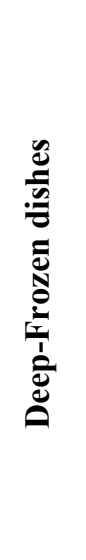 } & & $\begin{array}{l}\text { Savoy-style cooked } \\
\text { potatoes }\end{array}$ & $1.89 \pm 0.02$ & $78.34 \pm 2.36$ \\
\hline & & Paella & $1.88 \pm 0.01$ & $63.49 \pm 1.10$ \\
\hline & & tuna and potato gratin & $1.68 \pm 0.06$ & $59.49 \pm 6.55$ \\
\hline & & $\begin{array}{l}\text { Savoy-style baked } \\
\text { gratin }\end{array}$ & $1.63 \pm 0.05$ & $76.41 \pm 1.63$ \\
\hline & & Basque chicken & $1.50 \pm 0.01$ & $43.56 \pm 1.28$ \\
\hline & & Conchiglie with tuna & $0.89 \pm 0.21$ & $52.59 \pm 7.70$ \\
\hline & & $\begin{array}{l}\text { Farfallini with } \\
\text { gorgonzola }\end{array}$ & $0.78 \pm 0.01$ & $34.77 \pm 1.92$ \\
\hline & & $\begin{array}{l}\text { Rigatoni with tomatoes } \\
\text { and beef }\end{array}$ & $0.77 \pm 0.01$ & $44.71 \pm 1.40$ \\
\hline
\end{tabular}




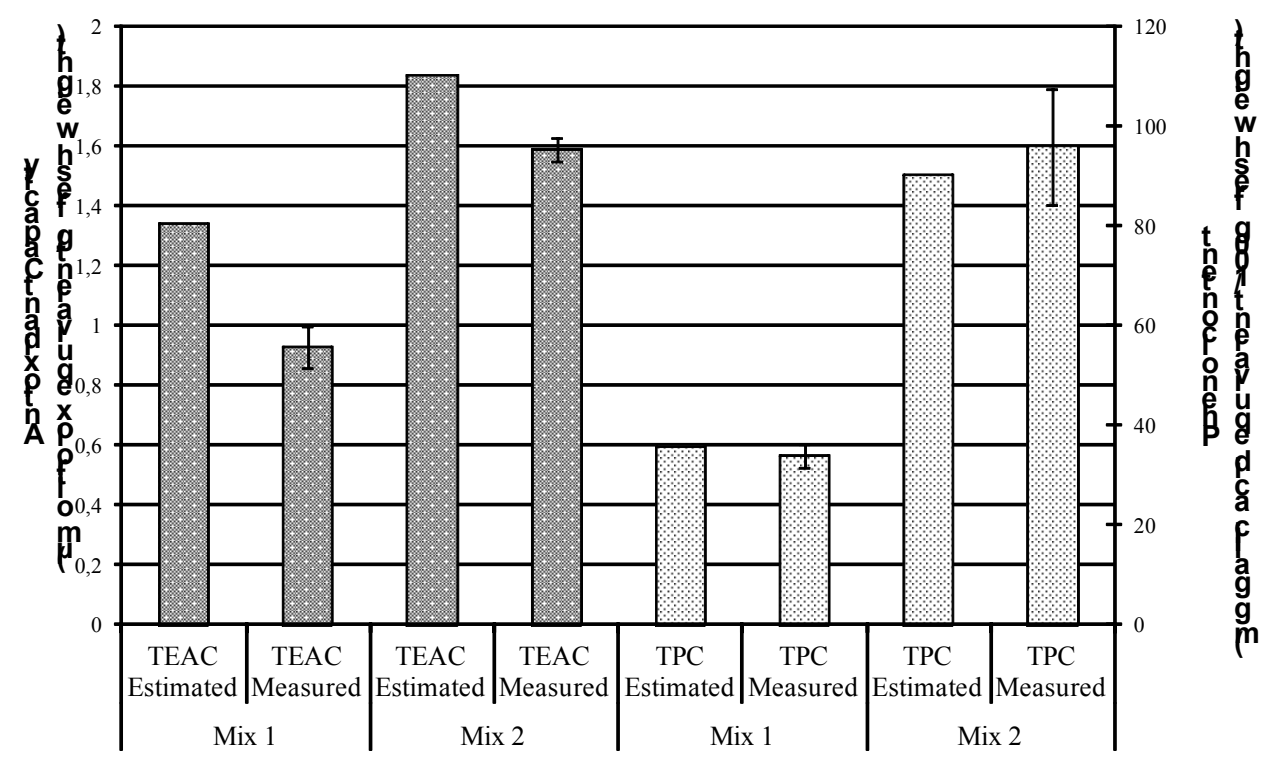

Figure 1. Interaction with food matrix: comparison between values estimated and measured. Mix 1 is a mixture of pie and parsley. Mix 2 is a mixture of fish, sauce and vegetables

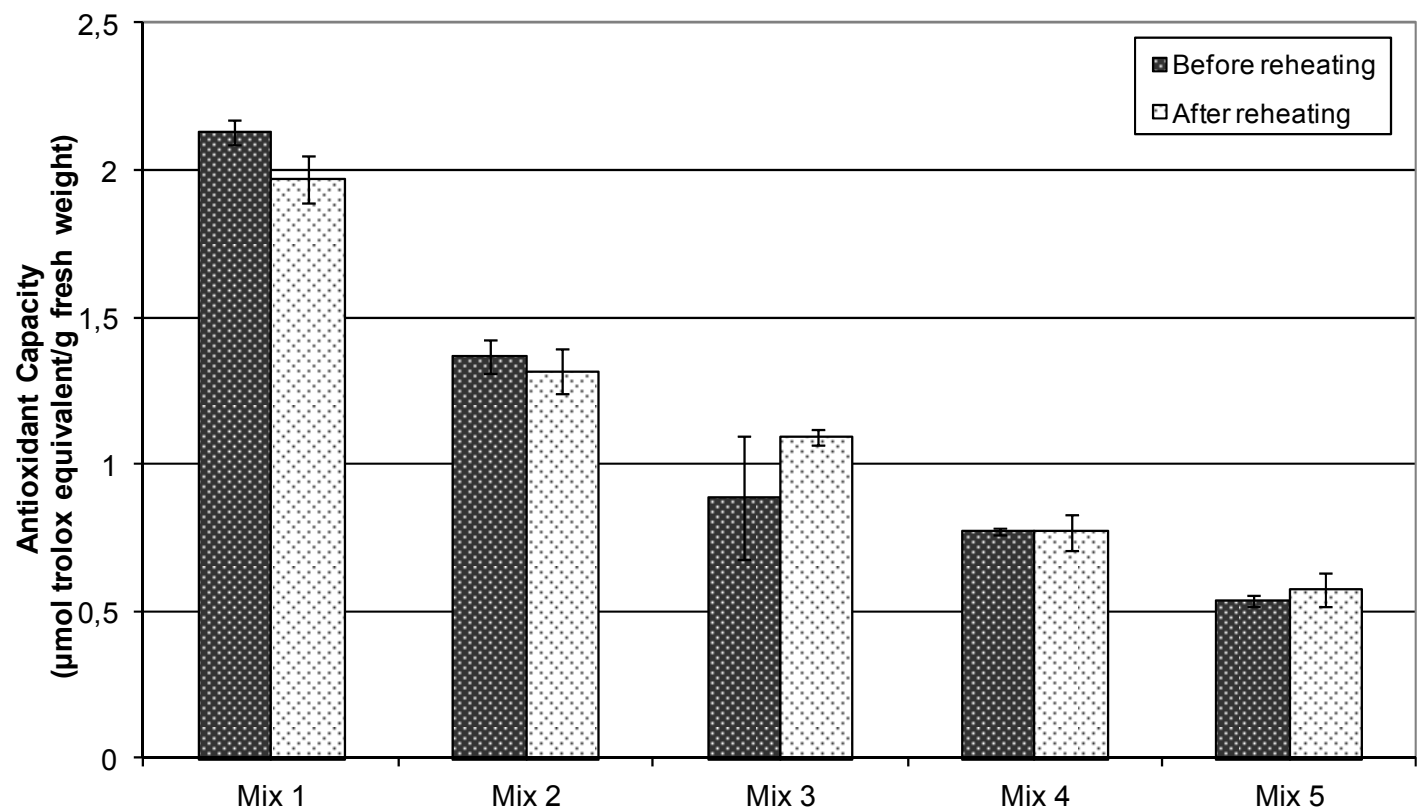

Figure 2. Effect of reheating on antioxidant capacity (TEAC) of convenience foods commonly consumed Mix 1 is a Provencal eggplant recipe. Mix 2 is Italian-style fish. Mix 3 is pasta with tuna. Mix 4 is pasta with beef and tomatoes. Mix 5 is a tuna and potato bake. 


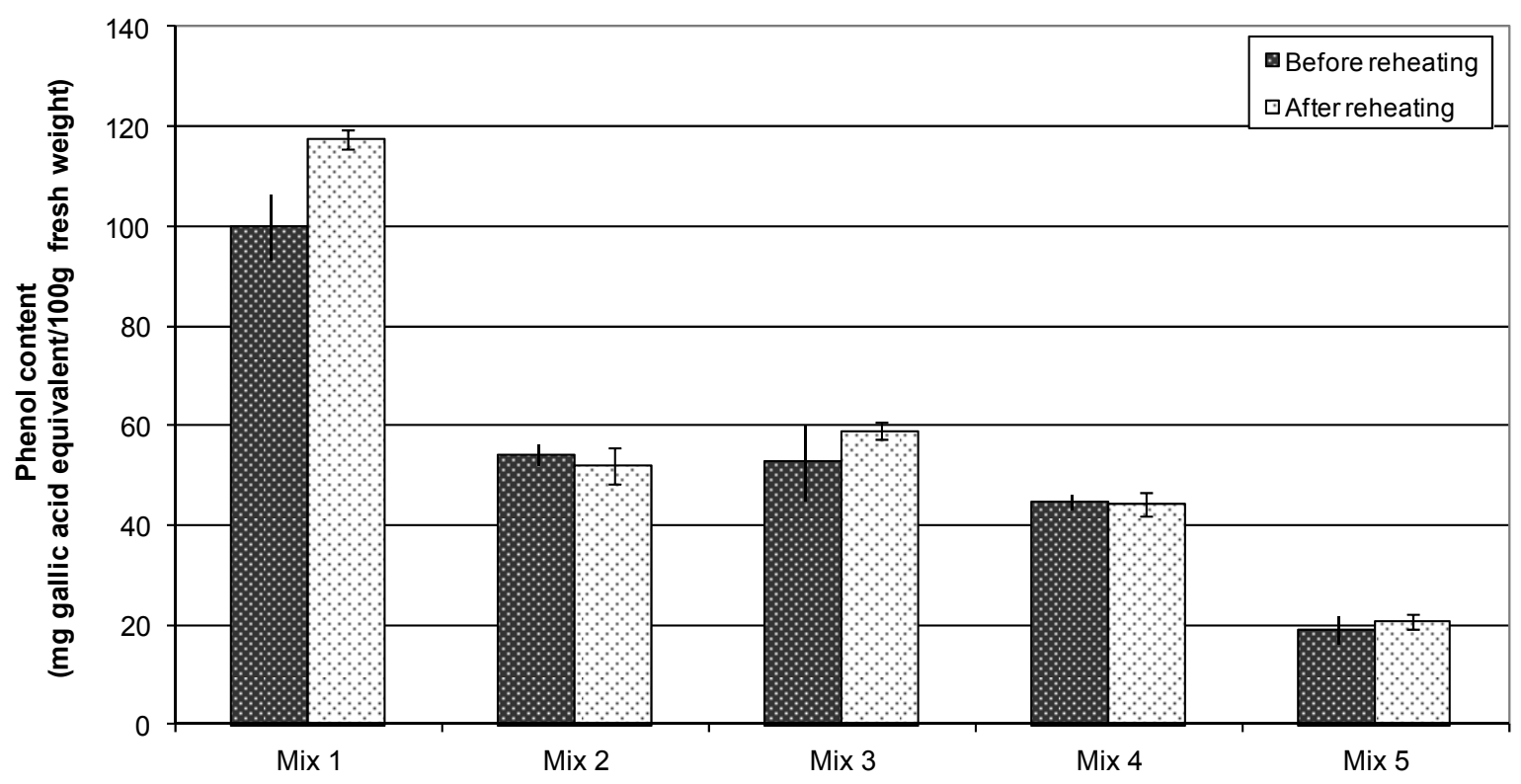

Figure 3. Effect of reheating on the Total Phenol Content of convenience foods commonly consumed 